\title{
渦流れが示唆する複雑流動の捉え方*
}

\author{
亀本 喬司**
}

\section{A Way to understand Complex Flows suggested by Vortex Flows}

\author{
Куојі KАмемото
}

\section{1 はじめに}

一般に渦流れを可視化観察すると，その渦がどのよj に生まれ，目の前でどのように変形し，どこへ流れ去る かを知ることに興味が向けられる。多くの場合，観察者 は渦の回転運動に注目し，渦の来し方，行く末を見届け ようと, 渦と共に視線を走らせる。この観察者の姿勢こ そいわゆるラグランジュ系の流体力学であり, 流れに 乗って渦運動を観察するほうが, 空間に視線を固定して そこを通過する流れを見つ省隹系よりも渦流れ の特徵を捉え易い。気象庁の台風情報などを見ても，台 風の動きを示すことにより, 周辺の風雨の状況変化が判 り易く説明されている。このように，渦流れはオイラー 系よりもラグランジュ系で捕らえるほうが直感的に理解 し易いことは，自然の知恵として明白である。

しかしながら, 流体力学上の多くの数学的取り扱いは, 固定座標からのオイラー系表現に基づいている。このた め，おもに差分を取り扱う CFD では非定常なはく離渦 流れの全容を計算の進行に沿って時々刻々観察すること は必ずしも容易ではない。これからは竜巻の発生予報や 空港周辺の気流速報など, 非定常流れのリアル夕イム解 析の必要性が高まっており，流れを目で追うようなラグ ランジュ系の流れの捉え方が注目され始めている.

本文では，渦流れの基本的な特性をラグランジュ系の 視点から見直し, 境界層のはく離や渦形成のメカニズム を平易に理解するための着眼点について説明する.さら に，ラグランジュ系の流れ解析法であるラグラジュ渦法 (Lagrangian Vortex Method) とそれによる数值解析 例を示し, 複雑な洞流れを対象とする数值可視化風洞と しての有用性を紹介する。

\section{2 渦流れのラグランジュ的視点}

\section{1 渦度分布の効果と渦度輸送}

渦流れを理解するための基本的な知識として, 渦度 (Vorticity)・渦（Vortex）・循環（Circulation）の相互 関係を明確に理解しておく必要がある.

* 原稿受付 2009 年 10 月 6 日

** 横浜国立大学名誉教授（广 228-0023 座間市立野台 2-23-31, E-mail : kamemoto@bg.mbn.or.jp)
渦度とは流れの中に存在する回転運動成分の度合いを

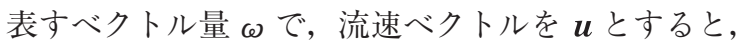

$\boldsymbol{\omega}=\operatorname{rot} \boldsymbol{u}$

で定義される。一般的には, 流れの中で渦度は流体の粘 性，密度勾配，衝撃波の作用によって生起される. ${ }^{1} ま$ た，流体の粘性が省略でき，いたるところで渦度が無く $\omega=0$ の流れはポテンシャル流れと呼ばれる.

渦を科学する上で重要な事柄のひとつは, 渦度の分布 がその周囲の流れに対してあたかもそこに自由渦が存在 するような効果をもっていることである.

Fig. 1 に示すよjに, 渦度 に任意の曲面 $S$ をとる，その面を囲む閉曲線によっ て定義される循環 $\Gamma$ が次のように得られる。(ストーク スの定理 (Stokes' theorem)

$$
\Gamma=\int_{C} u \cdot d l=\int_{S} \omega \cdot n d S
$$

上式は，循環の量を定義する基本的な式であるのみでな く, 流れ場に存在する渦度の分布がそれを取り囲む流体 に循環を生成しているという重要な意味を持っている。

生成された渦度は，流れに運ばれる間に流れの状態に よって回転軸方向に伸びて渦度の強さが増大したり，あ るいは粘性拡散によって減少し運動のエネルギーを熱工 ネルギーへと消散する．流れによって運ばれる渦度の増 減の様子を数学的に記述しているものが渦度方程式であ り，非圧縮性を仮定できる流れの場合，Navier-Stokes

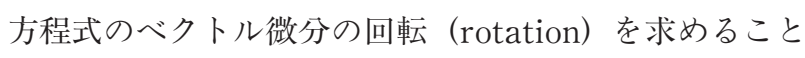
により，次のように表される。

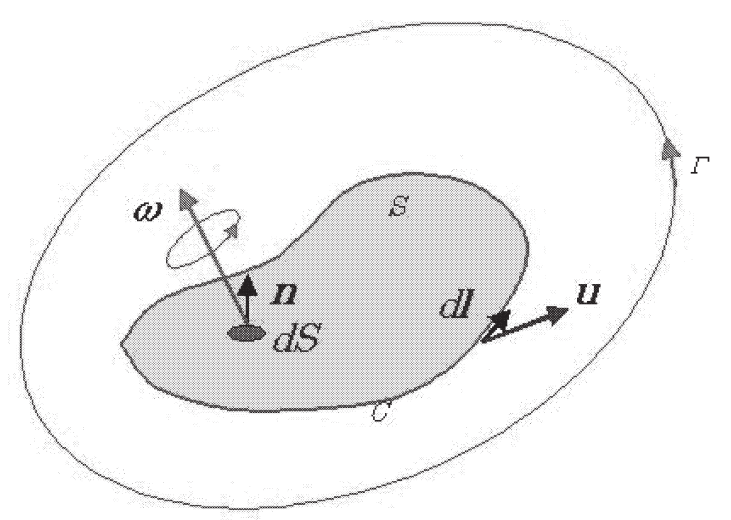

Fig. 1 Vortisity distribution and resultant circulation. 


$$
\frac{\partial \boldsymbol{\omega}}{\partial t}+(\boldsymbol{u} \cdot \operatorname{grad}) \boldsymbol{\omega}=(\boldsymbol{\omega} \cdot \mathrm{grad}) \boldsymbol{u}+\nu \nabla^{2} \boldsymbol{\omega}
$$

ただし， $\nu$ は流体の動粘性係数を表す。式(3)は，流れに よる渦度の移流や拡散を固定座標系（オイラー系）から 見な場合の記述である. 左辺の第 2 項はオイラー系独特 の非線形項であり，流れとともに渦度がどのように変化 するかを観察する場合に，直感的な理解が妨げられる。

また，渦度輸送を数值計算する場合には，この非線形項 の取り扱いに注意を払う必要がある。

一方, 渦度の移流と共に動く移動座標系（ラグラン ジュ系) では，渦度方程式は式(3)に代わって次のように 表される。

$$
\frac{d \boldsymbol{\omega}}{d t}=(\boldsymbol{\omega} \cdot \mathrm{grad}) \boldsymbol{u}+\nu \nabla^{2} \boldsymbol{\omega}
$$

式(4)は, 流れとともに動きながら渦度がどのような要因 によって時間的に変化するかを説明している。オイラー 系の式(3)とは異なり左辺に非線形項は無く, 渦度の時間 的な変化を右辺の変化要因と直接結び付けて理解するこ とができ，直感的に洞流れを捉え易い. 式(4)の右辺第 1 項は, 渦度がもつ回転軸の方向が変化したり, 回転軸の 方向に伸びて渦度の強さが増大したりすることによる渦 度の時間変化率を表している。また，第 2 項は粘性の作 用にもとづく渦度の生成あるいは拡散による渦度の時間 変化率を表している。

流れが二次元の場合には, 回転軸方向の伸び・縮み流 動は存在しないので式(4)の右辺第 1 項は常にゼロとなり, 渦度方程式は次式のようになる。

$$
\frac{d \omega}{d t}=\nu \nabla^{2} \omega
$$

式(5)から明らかなように, 流れが二次元の場合には渦度 は粘性にもとづく生成あるいは拡散のみによって変化す るので, 粘性力が慣性力に比べて小さくなる流れ（高レ イノルズ数流れ）では，渦度は時間的に変化しにくくな ることが理解できる.

渦度の分布している領域は周囲の流れに対してあたか もそこに自由渦が存在するような効果を有することはす でに説明したが, この効果は, 自由渦からの誘起速度と 同様に, 渦度の分布する領域からの誘起速度としてビ オ・サバールの法則（Biot-Savart's law）を用いて定量 的に評価される。 ${ }^{2)}$

$$
\begin{aligned}
& \boldsymbol{u}=\int_{V} \boldsymbol{\omega}_{0} \times \nabla_{0} G d v \\
& +\int_{S}\left\{\left(\boldsymbol{n}_{0} \cdot \boldsymbol{u}_{0}\right) \cdot \nabla_{0} G-\left(\boldsymbol{n}_{0} \times \boldsymbol{u}_{0}\right) \times \nabla_{0} G\right\} d s
\end{aligned}
$$

ここに，Gはラプラス方程式の基本解であり，流速を 求める位置 $\boldsymbol{r}$ と非積分点の位置 $\boldsymbol{r}_{0}$ の距離を $R=|\boldsymbol{R}|=$ $\left|\boldsymbol{r}-\boldsymbol{r}_{0}\right|$ とすると $G=1 / 4 \pi R$ (三次元流れ)，または $G=(1 / 2 \pi) \log (1 / R)$ (二次元流れ）と表される.式(6) の右辺第 1 項の積分は, 流れ場に分布する渦度の層から の誘起速度であり，第 2 項の積分は流れ場の境界面の速
度 $\boldsymbol{u}_{0}$ による誘起速度である。

渦による旋回流れのねじれ構造の度合いを定量的に表 すものとして, 流速べクトル $\boldsymbol{u}$ と渦度ベクトルゅの内 積をとったものが, その位置のへリシティ密度 (helicity density) であり, 次式で定義される. ${ }^{3)}$

$$
h_{d}=\boldsymbol{u} \cdot \boldsymbol{\omega}
$$

また，流れ場に分布している渦度領域の回転強さの度 合いを定量的に表すものとして, 渦度 $の$ 絶対值の 2 乗の半分を取ったものが, エンストロフィー密度（enstrophy density) であり, 次式で表される。

$$
\text { enstrophy density }=\frac{1}{2}|\omega|^{2}
$$

ヘリシティやエンストロフィーの量は, 主に乱流構造 の研究において多く扱われてきたが, 乱流の渦構造のみ でなく流体機器内の流れのはく離渦構造や地球規模に形 成される渦構造に至るまで, 統一的な視点から渦流れを 理解する上で基本的な量となる。

\section{2 渦度の分布と流れ場の形成}

直線直交座標系 $x, y, z$ においては $\omega\left(\omega_{\mathrm{x}}, \omega_{\mathrm{y}}, \omega_{\mathrm{z}}\right)$ の $z$ 成分 $\omega_{z}$ は, 流速べクトル $\boldsymbol{u}(u, v, w)$ に対して次式で与 えられる。

$$
\omega z=\frac{\partial v}{\partial x}-\frac{\partial u}{\partial y}
$$

Fig. 2 (a)に示すように，粘性の作用によって物体表面と 主流の間に形成される境界層（速度せん断層）において， 壁面に沿う流れ方向を $x$ ，それに垂直な方向を $y$ とする と, 式(9)の右辺第 2 項はいわゆる境界層の速度勾配であ り，粘性によって形成される速度勾配の大きさが境界層 内の流れの渦度そのものの強さに直結していることから, 壁面は渦度の層で覆われていることが理解できる。

すなわち，粘性の作用にもとづく滑り無し条件に対応 して，Fig. 2 (a)に示したように物体壁面近傍に速度こう 配を持つ流れの層 (境界層) が形成され, レイノルズ数 が大きい場合にはこの層は物体の大きさに比べて非常に 薄くなり，速度こう配は大きくなる．多くの壁付近の流 れでは，壁に垂直な流速成分 $v$ は比較的小さく $|v| \ll|u|$ であるから $\omega z \fallingdotseq 一 \partial u / \partial y$ となり, Fig. 2 (b)に示すよj に境界層は粘性の作用によって物体壁面と主流との間に 形成される回転方向の揃った渦度の層であることに注目 されたい.

このことを式(2)にあてはめると, 境界層の断面 $(y=$ $0 \sim \delta ）$ を微小時間 $d t$ の間に通過する循環量 $d \Gamma$ は,

$$
\begin{aligned}
& d \Gamma=\int_{s \omega} \cdot n d S=\int_{0}^{\delta}(-\partial u / \partial y)(u d t) d y \\
& =\left(-U^{2} / 2\right) d t
\end{aligned}
$$

となる。壁面に沿う微小距離を $d x=(U / 2) d t$ とおくと, $d \Gamma=-U d x \quad \therefore d \Gamma / d x=-U$

したがって，境界層の存在は，外側の流れに対して， 壁に沿って流れ方向の単位長さ当たりーUの循環が存 在することと等価であり, このことから Fig. 2 (c)に示 


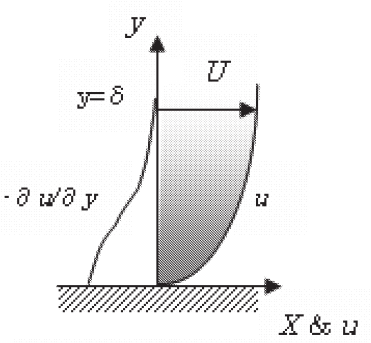

(a) Boundary layer

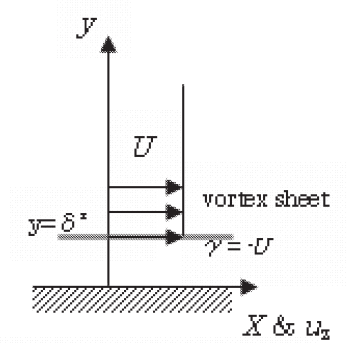

(c) Displacement thickness and wortex sheet.

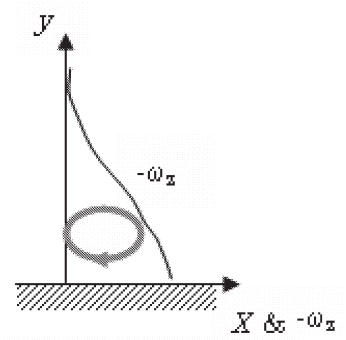

(b) Vortisity layer

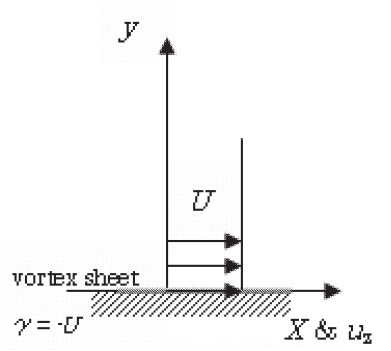

(d) Fotential flow

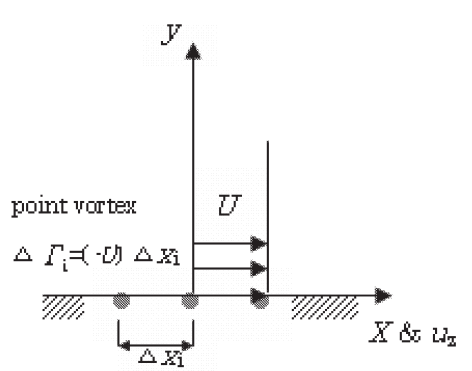

(e) Singularity method and wortex method

Fig. 2 Relation between boundary layer and vortex sheet.

すように境界層を排除厚さ $\delta^{*}$ に沿って分布する速度不 連続面（vortex sheet）で置き換えられることがわかる. さらに，レイノルズ数が大きい流れでは境界層厚さは物 体の大きさに比べて非常に薄くなるから，境界層の外の 流れに対して排除厚さ $\delta^{*}$ を省略し, Fig. 2 (d)に示すよ うに速度不連続面を直接物体周りに分布させることがで きる。これがいわゆるポテンシャル流れである。速度不 連続面は単位長さ当り $\gamma=-U$ の強さの循環分布であ るので，物体壁面上の微小長さ $\Delta x_{\mathrm{i}}$ の間にある循環量 $\Delta \Gamma=(-U) \Delta x_{\mathrm{i}}$ を同じ強さの自由渦点で近似的に置き 換えれば，それが 1900 年代の中頃まで翼列のポテン シャル流れ解析に多用された特異点法 (Singularity Method）である。

流体力学の多くの入門書では，ポテンシャル流れが実 際の粘性流れとは異なりかなり理想化された流れ（理想 流体の流れ）として別々に説明されているが，粘性に よって生成された渦度の分布が周囲の流れに対して自由 渦としての影響を有するということを認識すれば，粘性 流れもポテンシャル流も互いにそれほどかけ離れたもの ではないことがわかり，そこに新たな流体力学上の視野 が広がる。

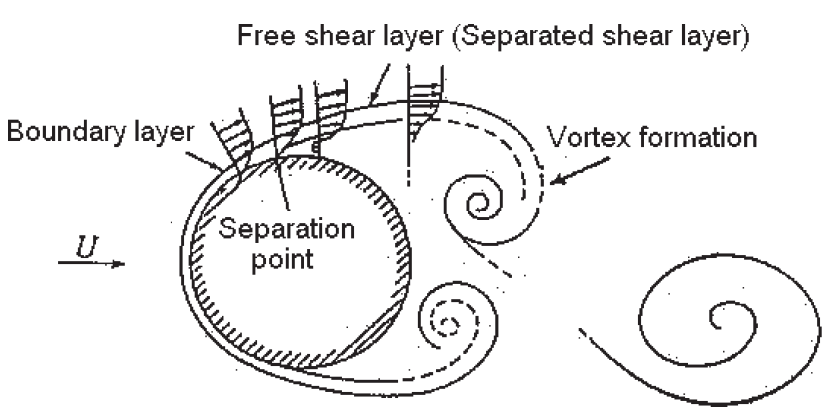

Fig. 3 Separation of vorticity layer and formation of large vortex structure.

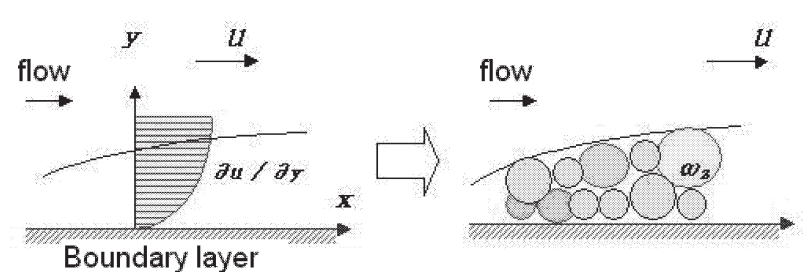

Boundary layer

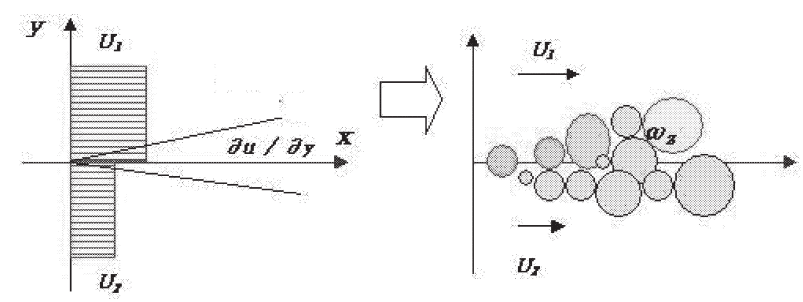

Mixing layer

Fig. 4 Modeling of velocity shear layer by discrete vortex elements.

このような周囲の流れに対する渦度分布の効果を考え ると，境界層が壁面からはく離して渦度の層が後流中に 放出され，それらが集まり大きな渦構造を形成するメカ ニズムが定性的に容易に理解できる (Fig. 3 参照).

上述の説明は境界層のみならずはく離せん断層や混合 層にも適用できる，流れの中におけるこれらの渦度の層 の発達や渦構造の形成の過程を詳しく理解するために,

Fig. 4 に示すように多数の微小な渦要素の分布によって 境界層や混合層をモデル化し，各渦要素の移流を時々 刻々追跡することにより複雑な渦流を数值的に解析する ことができる。この概念を応用し Rosenhead $\left.{ }^{4}\right)$ は混合層 における渦構造の形成を数值的に実証した. Rosenhead のアイディアは，格子生成や乱流モデルを必要としない 新しい渦法 (Vortex Method) ${ }^{5,6,7)}$ 一発展し, 最近で は複雑な渦流れの簡便な数值可視化実験ツールとして工 学的に利用されている。

\section{3 渦流れを捉える}

\section{1 渦度層の放出}

Fig. 5 に示すように壁面流線（限界流線）によって表 される渦度層の離脱の基本的な形態には, 一般的な三次 元はく離として知られる通常タイプの ordinary separation, 二次元はく離として知られる特異タイプの 

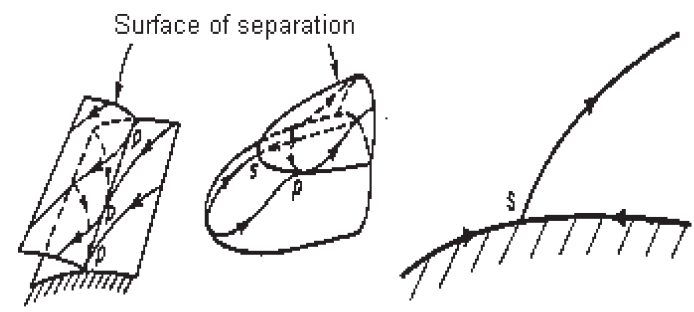

(a) Ordinary separation

(b) Singular separation

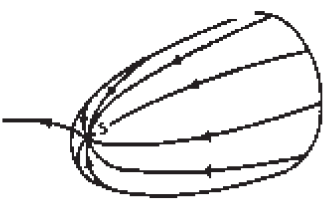

(c) Isolated separation

Fig. 5 Three types of separation of shear layer.

singular separation，後方よどみ点などの局所的な渦度 の離脱として知られる孤立夕イプの isolated separation point の三種がある. ${ }^{8)}$

物体後流に放出される渦の形態は流体抗力に直接影響 を与えるから，はく離にもとづく渦度の離脱様式は流れ 場全体を支配するが，物体形状のみからはなかなかこれ ら三種の渦度の離脱様式を的確に予測することはできな い. 多くの場合下流に形成される渦からの誘起速度によ り渦度層の離脱様式も変化する。

Fig. 6 に示すように例え物体が二次元的な円柱で境界 層の発達が二次元的であっても，はく離流れは後流から の影響（feed back 作用）により三次元的となり，形成 される後流渦や円柱背面のはく離域の流れには三次元性 が顕著に現れる。9

\section{2 渦法による数値可視化実験}

Fig. 7 に示すように，一般に物体が静止していても振 動していても，物体周囲の流れが時間的に変化する非定 常流れでは，物体まわりの渦度分布は時間的に変化し， その結果物体まわりの循環 $\Gamma(t)$ も時間的に変動する. いま微小時間 $d t$ の間に物体まわりの循環が $\Delta \Gamma$ だけ変 化したとすると, 逆向きの循環量 $(-\Delta \Gamma)$ が物体から 下流に放出される。(ケルビンの循環定理（Kelvin's circulation theorem))

循環の流出は, 具体的には物体壁面から流下する全渦 度分布層の正味の循環量であり, 流出循環の絶対值 $|\Delta \Gamma|$ が大きいほど物体下流壁面近傍で強い渦に巻き上 がる.このメカニズムによって流れの非線形性が次のよ うに理解できる。すなわち，揚力と循環の関係から物体 を囲む循環の変化は物体に作用する流体力の変化と直結 していて，この流体力の変化は下流への渦放出とも強く 結ばれる。

渦度の分布する領域として物体まわりの境界層全体を 考えると，渦度分布により形成される循環 $\Gamma$ はこの物 体周りの循環を表し，翼の揚力発生のメカニズムが粘性 による境界層の形成と深く結びついていることがわかる.

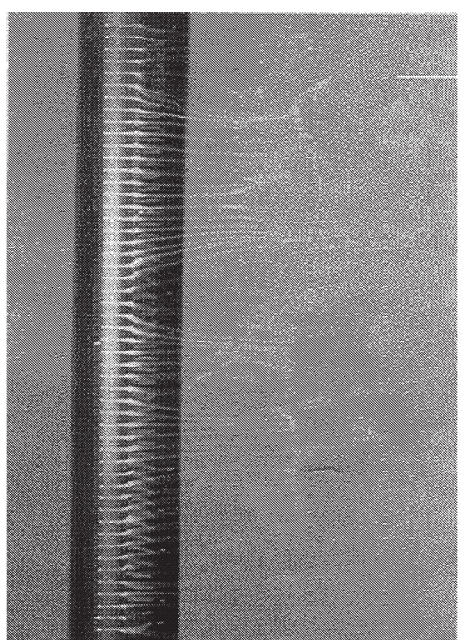

(a) Visualized flow around a circular cylinder in a towing tank $(\mathrm{Re}=570)$

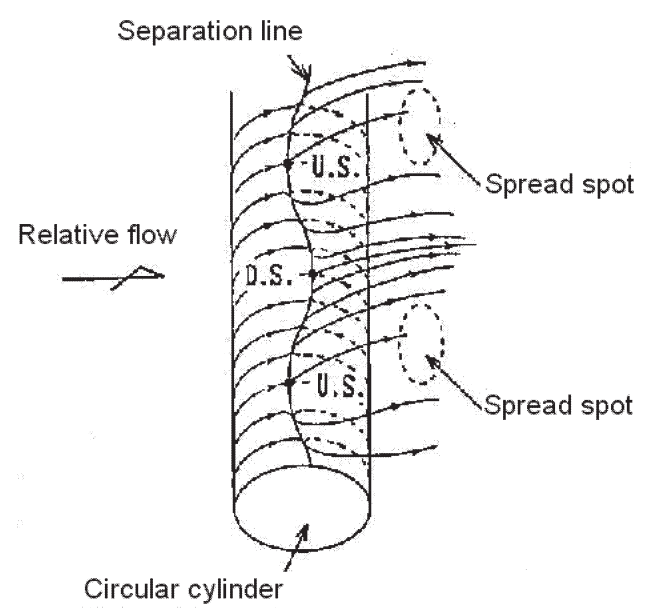

- Singular separation point $\left(\tau_{\mathrm{w}}=0\right)$

U.S.: Upstream singular separation point

D.S.: Downstream singular separation point

(b) Sketch of the three-dimensional structure of the flow

Fig. 6 Three-dimensionality of flow separation around a circular cylinder.

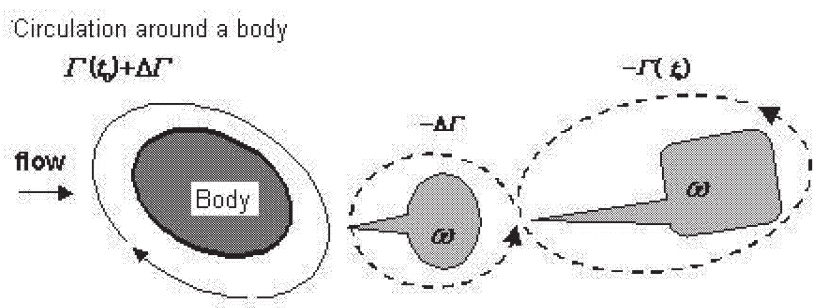

Fig. 7 Change of circulation around a body.

Fig. 8 は, 静止流体中で突然一定速度 $(U)$ で走り出 したNACA 4412 翼周りの流れの渦法による数值シミュ レーション結果である。解析条件は翼から見た相対流れ の一様流速 $U=30 \mathrm{~m} / \mathrm{s}$, 迎角 $\alpha=10^{\circ}$, 翼弦長 $c=1.0$ $m, R e=6.8 \times 10^{4}$ である. 流れの出発時 $(t=0.0 s)$ か 


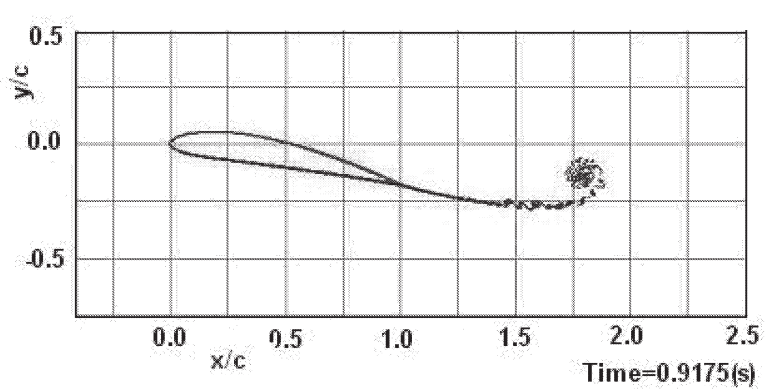

(a) Shedding of starting vortex

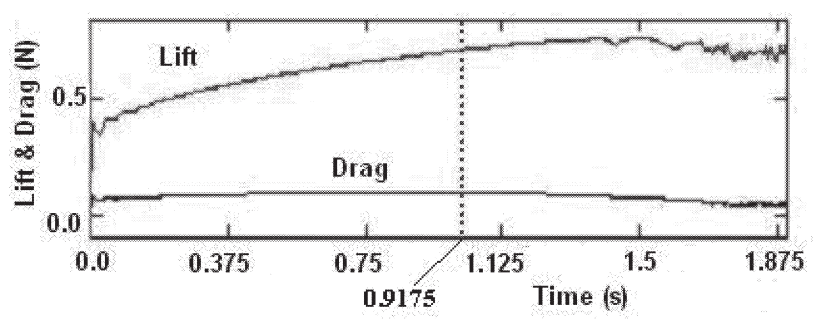

(b) Time-evolution of lift and drag forces

Fig. 8 Starting flow around an airfoil (NACA 4412, attack of angle $(\alpha)=10^{\circ}$, starting flow velocity $(U)=1 \mathrm{~m} / \mathrm{s}$, cord length $\left.(c)=1 \mathrm{~m}, R e=6.8 \times 10^{4}\right)$

ら翼周りに循環が発達するのと同時に，翼の上面及び下 面で発達した境界層が翼端から流れ出し, 翼周りに発達 する循環とは回転が逆の循環を持つ出発渦が流れ出して (Fig. 8 (a)参照)，翼面に作用する揚力及び抗力は時間と 共に増大する。その後時間が経過すると共に出発渦は遠 方に流下し, 揚力および抗力はそれぞれピーク值に達し た後やや減少して一定值に漸近する (Fig. 8 (b)参照). なお，本計算条件では，さらに時間が経過すると境界層 がより一層発達してはく離発生の傾向が現れ，流れが不 安定となりこれによる微弱な揚力変動が観察される.

Fig. 9 は, 遊泳する魚の周囲に形成される非定常で複

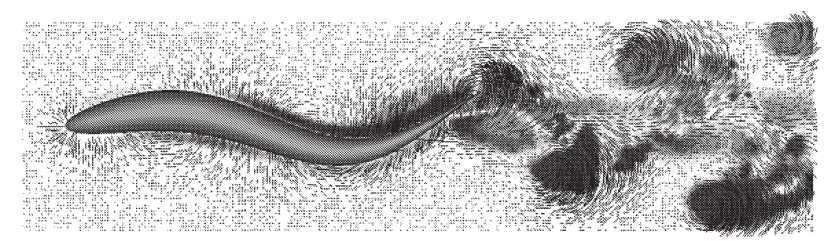

(a) Instantaneous velocities and the $z$ component of vorticity $\omega_{z}$ distributions at middle plane $(z=0)$.

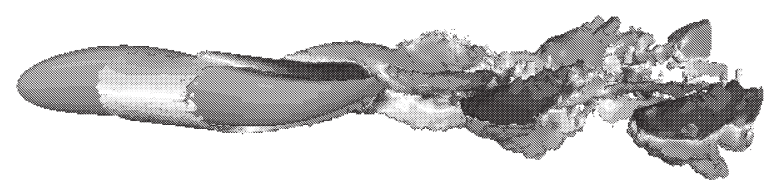

(b) Isosurfaces of vorticity magnitude of $|\omega|=10$

Fig. 9 Instantaneous flow structure around a swimming trout by vortex method.
雑な渦構造を持つ流れの渦法による数值シミュレーショ ン結果である。 ${ }^{10}$ 魚体は鱒で体長 $L$, 遊泳速度 $U$, 尾の 振動数 $f$, 頭部の片振幅 $a_{0}=0.023 L, R e=U L / \nu=10^{4}$ （ $\nu$ は動粘性係数）として, 鱒の波動運動を表すために, 頭部 $(x / L=0)$ から尾端 $(x / L=1.0)$ にかけての魚体中 心線の運動 $h(x, t)$ が次式の正弦進行波数学モデル11)で 近似的に与えられている。

$$
h(x, t)=a_{0} \exp (b x) \cos \left\{\frac{2 \pi}{\lambda}(c t-x)\right\}
$$

ただし， $b$ ：振幅増大率 $=1.34 / L, c$ : 変形波の伝播速 度, $h$ : 変形振幅, $\lambda$ : 波長 $=0.87 L, t$ : 時間である. このとき, 振動周波数は $f=c / \lambda$, 無次元位相速度は $S_{\mathrm{p}}=c / U$, 泳動数 (swimming number) は $S_{\mathrm{w}}=U /$ $f L=0.87 / S_{\mathrm{p}}$ であり, Fig. 9 に示された流れの遊泳条件 は, $S_{\mathrm{p}}=2.175(S w=0.40)$ である.

Fig. 9 (a)は, 魚体の中央断面の二次元的なフローパ ターンを示すもので，図中で頭部から上面および下面に 沿って発達した境界層が尾端で交互に交差的に放出され， カルマン渦列状で渦の回転は逆の一対の渦列（逆カルマ ン渦列）構造が形成されることがわかる.

Fig. 9 (b)は, 同一条件における流れの三次元構造を示 すものであり, 魚体中央から尾部にかけて背びれ部位に 波動運動による縦渦構造が形成され, 尾端から放出され た逆カルマン渦構造と結合していることがわかる.

Fig. 10 は， 5 種類の泳動数 $\left(S_{\mathrm{w}}\right)$ に対する渦法による 流れ解析から得られた魚体に働く流体力を、摩擦抗力係 数 $\left(C_{\mathrm{xf}}\right)$, 圧力抗力係数 $\left(C_{\mathrm{xp}}\right)$ および有効推進力係数 $\left(C_{\mathrm{xt}}=C_{\mathrm{xf}}+C_{\mathrm{xp}}\right)$ とともに, それぞれに対する遊泳の推 進エネルギー効率 $\left(\eta_{\mathrm{p}}\right)$ を示したものである. 有効推進 力係数 $C_{\mathrm{xt}}=0$ となって圧力推進力と摩擦抗力がバラン スして等速度運動（巡航遊泳）が得られるときの泳動数 は約 0.63 となっており、多くの種類の実際の魚の観測 から得られている值 $(0.6 \sim 0.75)^{12)}$ に近い.さらに，こ の等速度運動が得られる泳動数付近で推進エネルギー効 率 $\left(\eta_{\mathrm{p}}\right)$ は最大となり，64.1\%という非常に高い効率が 得られ, 実際の魚から求妨れる推測值 ${ }^{13)}$ と良く一致し ている。

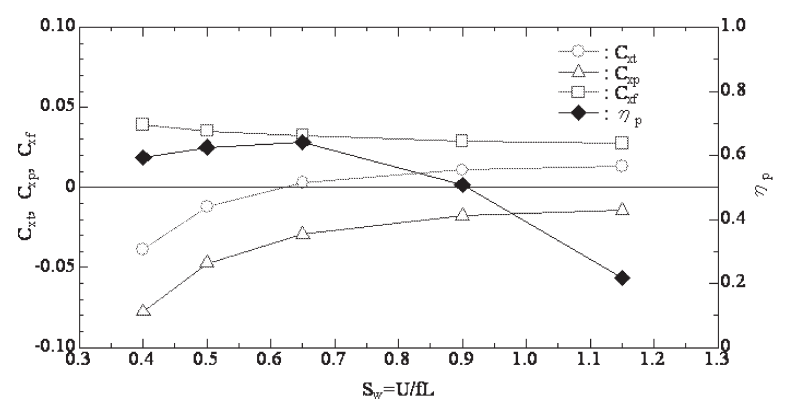

Fig. 10 Coefficients of surface frictional force $\left(\mathrm{C}_{\mathrm{xf}}\right)$, surface pressure force $\left(\mathrm{C}_{\mathrm{xp}}\right)$ and resultant thrust force $\left(\mathrm{C}_{\mathrm{xt}}=\mathrm{C}_{\mathrm{xf}}+\mathrm{C}_{\mathrm{xp}}\right)$ acting on a swimming trout, and efficiency of the propulsion motion $\left(\eta_{\mathrm{p}}\right)$ 


\section{4 むすび}

実際の渦流れを観察すると, 渦度の生成, 輸送, 拡散, そして渦構造の形成, 変形, 消滅が, 複雑な渦流動の現 象を支配していることは確かである、コーヒーカップの 中でミルクによって可視化された渦を観ていると，大小 の渦が混ざり合ってゆくプロセスが美的に面白く，つい 時間を忘れることがある。これはまさしくラグランジュ 系の視点で物理的な流れ構造を捉えるからこそ得られる 価值ある「納得」である。

一方，天文宇宙の世界では銀河系の星雲が見事な渦構 造を持っている写真をよく目にする. 星雲の渦構造をよ り詳細に観察すると, 太陽系のような惑星の集団やガス からなる小規模渦構造が多数存在している.太陽系の惑 星である地球は, 星雲という巨大な渦構造の一要素であ ることに気が付けば，渦運動が流体という連続性を仮定 した古典的流体力学を超えた自然現象であることは否定 できない.コーヒーカップの渦も $\mathrm{H}_{2} \mathrm{O}$ の水分子を始め 様々な分子や原子の集まりであり，極限的に見れば連続 体の仮定は成り立たないことと同様である.

本文では，渦流れをラグランジュ系の視点から微小な 渦要素一つ一つの流動の集合として理解する捉え方につ いて説明した. 実験観察においてもCFD 解析において も，ラグランジュ系の視点が，渦構造の本質を解き明か す有効な近道であることをご理解いただけたなら筆者の 喜びとするところである.
参考文献

1) Green S.I. (ed.) : "Fluid Vortices", KLUWER ACADEMIC PUBLISHERS (1995) pp.1-34.

2) Wu, J.C. and Thompson, J. F. : Numerical Solutions of Time-Dependent Incompressible Navier-Stokes Equations using an Integro-Differential Formulation, Computers \& Fluids, 1 (1973) pp.197-215.

3 )「ながれの事典」, 神部勉編, 丸善 (2004) pp.338-339.

4 ) Rosenhead, L. : The formation of vortices from a surface of discontinuity, Proc. Roy. Soc. (London) A 134 (1931) pp. 170-192.

5 ) Cottet, G. H., Michaux, B., Ossia, S. and VanderLinden G. : A comparison of spectral and vortex methods in threedimensional incompressible flows, J. of Computational. Physics 175 (2002) pp.702-712.

6 ) 亀本喬司, 木田輝彦：渦法の現状, 機論（B編), 69-683 (2003) pp.1564-1569.

7 ) Kamemoto, K., : Recent contribution of an advanced vortex element method to simulation of unsteady vortex flows, Computational Fluid Dynamics Journal, 15(4) : 55 (2007) pp.422-437.

8 ) Chang P. K.: "Separation of Flow". Pergamon Press (1970) pp.31-32.

9 ）横井嘉文, 亀本喬司 : 二次元的な境界層はく離流れに潜在す る初期の三次元渦構造（円柱上層流境界層はく離のはく離域 側からの可視化観 測), 機 論 (B 編), 57-541 (1991) pp. 3273-3277.

10) Kamemoto K. and Ojima A. : Vortex method for the analysis of complex, unsteady and vertical flows around a swimming fish, Advances in Science and Technology, Trans Tech Publications, Switzerland, Vol.58 (2008) pp.183-192.

11）東昭, : “生物の動きの事典”, 朝倉書店（1997） pp.141-183.

12）田中一朗, 永井實, : 抵抗と推進の流体力学一水棲動物の高速 遊泳能力に学ぶ一, シップ・アンド・オーシャン財団 (1996) pp.144-148.

13）H. Hertel,著, 土屋喜一 (訳) : “バイオエンジニアリング : 生物の形と運動に学ぶ”, 朝倉書店（1985） pp.140-168. 